\begin{tabular}{l|l|l} 
Jurnal Eksplorasi Akuntansi & $\begin{array}{l}\text { ISSN : 2656-3649 (Online) } \\
\text { Vol. 2, No 1, Seri D, Februari 2020, Hal 2466-2478 }\end{array}$
\end{tabular}

\title{
PENGARUH KUALITAS AUDIT, LINGKUP AUDIT DAN GAYA KEPEMIMPINAN TERHADAP EFEKTIVITAS PENGENDALIAN INTERNAL DI SEKTOR PEMERINTAH
}

\author{
Ivand Satria $^{1}$, Mia Angelina Setiawan ${ }^{2}$ \\ ${ }^{1}$ Alumni Jurusan Akuntansi Fakultas Ekonomi, Universitas Negeri Padang \\ ${ }^{2}$ Jurusan Akuntansi Fakultas Ekonomi, Universitas Negeri Padang \\ *Korespondensi: ivandsatriaa@gmail.com
}

\begin{abstract}
The study aims to know how to describe and partially test assumptions in the quality of the audit, the scope of the audit, and the leadership style which are proxy with the variables of Independence and, on the Effectiveness of Internal Control in the Government which are analyzed using multiple linear regression. The sampling technique used is quota sampling. The results showed that the quality of the audit did not affect the effectiveness of the internal control. The scope of the audit did not show any effect on the effectiveness of the internal control. And leadership style has an impact on the effectiveness of internal control.
\end{abstract}

Keyword : Audit Quality, Audit Scope, Efectiveness of Internal Control, Government, Leadership Style.

How to cite (APA $6^{\text {th }}$ style):

Satria, Ivand \& Setiawan, Mia Angelina. (2020). Pengaruh Kualitas Audit, Lingkup Audit Dan Gaya Kepemimpinan Terhadap Efektivitas Pengendalian Internal Di Sektor Pemerintah. Jurnal Eksplorasi Akuntansi, 2(1), Seri D, 2466-2478.

\section{PENDAHULUAN}

Pelaksanaan sistem pemerintahan di Indonesia mewajibkan pemerintah untuk lebih transparan dan akuntabel dalam menjalankan otonomi daerah. Agar tidak terjadinya kecurangan (fraud) pada sektor pemerintahan di Indonesia ini maka diperlukan pengawasan yang baik, karena hal utama yang menyebabkan terjadinya kecurangan ialah lemahnya pengendalian internal.

Hasil audit BPK RI Tahun 2018 ditemukan bahwa lemahnya pengendalian internal di sektor pemerintahan, yaitu banyaknya Kepala Daerah yang tertangkap korupsi meski mendapatkan opini WTP (IICW, kompas.com 2018). Sumatera Barat merupakan salah satu daerah yang memiliki kecurangan yang tinggi, hal ini di dukung melalui temuan BPK RI perwakilan Sumatera Barat karena ditemukannya SPJ Fiktif di Dinas Prasarana Jalan, Tata Ruang dan Pemukiman Sumatera Barat yang sekarang disebut dengan Dinas Pekerjaan Umum dan Perumahan Rakyat sebesar Rp. 43 M (Haluan 30 Mei 2017). Melihat dari permasalahan yang dialami Sumatera Barat ialah dari sistem pengendalian internal, dimana dari temuan di atas membuktikan adanya masalah pada sistem pengendalian internal. Efektivitas pengendalian internal ialah salah satu kriteria 
pemberian opini yang di tetapkan oleh BPK RI yang mana laporan dari hasil pemeriksaan tersebut dituangkan dalam Laporan Hasil Pemeriksaan atas Sistem Pengendalian Internal.

IAI (2001) menemukan pengendalian internal merupakan suatu proses yang dijalankan oleh dewan komisaris, manajemen, dan semua personil entitas guna untuk memberikan keyakinan yang memadai untuk mencapai tiga tujuan organisasi yaitu (1)keandalan laporan keuangan, (2)efektivitas dan efisiensi operasi, dan (3)kepatuhan terdadap hukum serta peraturan yang berlaku. Dengan demikian dapat disimpulkan bahwa efektifitas pengendalian internal memiliki peranan yang sangat penting bagi organisasi termasuk dalam Pemerintah Daerah. Pemerintah Daerah harus mampu menjalankan pengendalian internal yang efektif agar memperoleh keyakinan yang memadai guna mencapai tujuan.

Faktor -faktor yang mempengaruhi efektivitas pengendalian internal sangat banyak baik dari internal maupun eksternal, salah satunya dari faktor eksternal yakni kualitas audit. Susiani (2017) menjelaskan kegiatan yang dilakukan dengan tujuan pemeriksaan oleh auditor mutu internal dan eksternal atau audit bahwa kualitas audit ialah suatu bagian penting dari sistem manajemen mutu dan merupakan elemen kunci dalam sistem standar mutu.

Susiani (2017) menyebutkann dalam penelitiannya pada pegawai Bank Jabar Banten Kota Bandung sebanyak tiga puluh responden yang menguji kualitas audit terhadap efektivitas pengendalian internal yang mana hasil ditemukan bahwa kualitas audit berpengaruh positif terhadap efektivitass pengendalian internal. Dalam hasilnya tersebut terbukti kualitas audit sangat berpengaruh terhadap efektivitas pengendalian internal pada Bank Jabar Banten di Kota Bandung.

Lingkup audit merupakan suatu batasan pemeriksaan bagi pemeriksa untuk dapat menerapkan prosedur, yang ditentukan berdasarkan sasaran, lokasi, dan waktu. BPK RI (2010) menjelaskan lingkup audit ialah batas pemeriksaan yang harus terkait langsung dengan tujuan pemeriksaan. Dalam SPKN BPK RI, lingkup audit diartikan sebagai batas pemeriksaan dan harus terkait langsung dengan tujuan pemeriksaan. Pembatasan lingkup audit yang dikenakan klien maupun oleh keadaan, seperti waktu pelaksanaan audit, besar kecilnya lingkup pemeriksaan, kegagalan memperoleh bukti yang cukup, atau ketidakcukupan catatan akuntansi menyebabkan baik buruknya efektivitas pengendalian internal.

Dewi (2015) dalam penelitianya yang berjudul pengaruh independensi, pengalaman kerja, keahlian professional, motivasi, dan ruang lingkup pekerjaan audit pengawas pada efektivitas pengendalian internal koperasi pada koperasi di Kecamatan seriirit menemukan bahwa ruang lingkup audit berpengaruh simultan terhadap efektivitas pengendalian internal. Penelitian Yadyana (2006) menunjukan adanya keterkaitan keahlian professional, lingkup audit, pelaksanaan pekerjaan pemeriksaan, dan pengelolaan bagian pemeriksaan terhadap efektivitas pengendalian internal. Hasil dari penelitian Yadyana menjelaskan bahwa lingkup audit terbukti mempunyai pengaruh yang signifikan terhadap efektivitas pengendalian internal.

Gaya kepemimpinan ialah suatu seni dan ilmu pengetahuan untuk mengajak atau mendorong orang lain dalam menjalankan kewajiban secara maksimal. Kartono dalam Wicaksono (2013) mengatakan bahwa kepemimpinan diartikan sebagai suatu bentuk dominasi yang didasari atas kemampuan pribadi yang sanggup mendorong atau mengajak orang lain untuk berbuat sesuatu yang berdasarkan penerimaan oleh kelompoknya dan memiliki keahlian khusus dalam situasi yang juga khusus.

Wijawa, dkk (2016) yang meneliti tentang analisis pengaruh independensi, motivasi, pengalaman kerja, profesionalisme, dan kepemimpinan terhadap efektivitas pengendalian internal yang memperoleh hasil bahwa kepemimpinan berpengaruh signifikan terhadap efektivitas pengendalian internal. Rae dan Subramanian (2008) dalam penelitianya juga ditemukan terdapat 
pengaruh antara lingkungan yang etis dengan prosedur internal control yang memoderasi adanya pengaruh antara keadilan organisasi terhadap kecurangan karyawan. Hasil tersebut mengasumsikan bahwa semakin baik kepemimpinan dalam suatu organisasi, maka semakin efektif pengendalian internalnya sehingga semakin rendah tingkat terjadinya kecurangan (fraud) dalam organisasi tersebut.

COSO dalam Wicaksono (2013) menemukan bahwa lingkungan yang etis dari suatu organisasi meliputi berbagai aspek dari kepemimpinan top manajemen dalam mencapai sasaran organisasitoris, nilai-nilai mereka dan manajemen.

\section{REVIU LITERATUR DAN PENGEMBANGAN HIPOTESIS Teori Agensi}

Menurut Jensen dan Meckling (1976) teori agensi ialah kontak di mana satu atau lebih orang memsnggil kepala sekolah, merekrut dan mengotorisasi satu atau lebih orang lain, yang kemudian dipannggil agen untuk melakukan tugas dan membuat keputusan untuk kepentingan kepala sekolah. Penerapan Teori Agensi dalam kegiatan lingkup pemerintahan dapat dilihat bahwa pemerintah sebagai otoritas (agen) kepada pihak luar, yaitu auditor BPK RI.

Pertentangan kepentingan yang menimbulkan tarik menarik kepetingan antara principal dana gen menyebabkan terjadinya permasalah. Agency Theory sehingga ditemukan asimtri informasi yang non setara dengan principal dana gen. manajer dalam prakteknya cenderung mencari output yang dapat menjanjikan. Tingginya asimetri informasi menimbulkan keingin besar kepada manajer tersebut untuk memanipulasi hasil kerja untuk kepentingan pribadi.

\section{Signalling Theory}

Spence (1973) menemukan bahwa teori pensinyalan menunjukkan asimetri informasi antara pihak-pihak yang terkait dengan manajemen melalui publikasi informasi. Di lembaga pemerintah, teori pensinyalan menyarankan bagaimana kepemimpinan di lembaga pemerintah harus memberikan referensi kepada pimpinan departemen dan karyawan yang berurusan langsung dengan kegiatan manajemen lembaga. Dalam memberikan acuan - acuan untuk keputusan yang akan dijadikan dasar keputusan, pemimpin memiliki kemampuan yang kompetitif untuk bawahan.

Referensi ini dapat berupa informasi yang telah dilakukan oleh pimpinan untuk memenuhi keinginan atau keinginan bersama instansi pemerintah dalam mengembangkan dan meningkatkan kinerja instansi pemerintah. selanjurtnya setiap keputusan yang akan digunakan dalam kegiatan operasi, perushaan bermaksud untuk meningkatkan nilai dari perushaan agar tetap berjalan di masa depan.

\section{Efektivitas Pengendalian Internal}

Menurut Ravianto (2014: 11), efektivitas ialah seberapa sukses suatu organisasi sejauh orang menghasilkan output yang maksimal. Ini berarti bahwa jika pekerjaan dapat diselesaikan dengan perencanaan, waktu, biaya, dan kualitas, maka pekerjaan tersebut dapat dikatakan efektif. Iinternal perusahaan memiliki peran diaman setiap pegawai, dalam perushaan tersebut dapat menjadi aspek yang memberikan dapak yang pasti. Oleh karena itu, efektivitas terkait dengan pencapaian tujuan, dan efektivitas dapat dicapai dengan menerapkan proses sesuai dengan tujuan yang diharapkan. Jika tujuan perusahaan tercapai, mereka dapat digambarkan secara efektif.

Pengendalian internal ialah proses yang terdiri dari kebijakan dan prosedur yang dibuat untuk dilakukan oleh stiap produksi akan memberikan peningkatan nilai dari perushaan secara tidka langsung sehingga dampak yang diberikan secaara nyata. semua orang yang memberikan 
kepercayaan yang memadai dalam mencapai tujuan yang saling terkait tertentu di mana implementasi memberikan hasil yang memuaskan, dan menunjukkan tingkat kesesuaian antara tujuan yang dinyatakan dan semua hasil yang dicapai. (Mulyadi, 2008).

\section{Lingkup Audit}

Guy, et al (2001: 14) mengatakan bahwa ruang lingkup audit menemukan kemampuan auditor untuk melaksanakan prosedur audit yang diperlukan. Jika audit tidak dapat dilakukan dengan benar, auditor tidak akan dapat memberikan pendapat yang wajar tanpa kecuali. Ruang lingkup audit berarti batas audit, artinya efektivitas pengendalian internal akan dipengaruhi oleh batas audit yang diberikan oleh klien kepada auditor.

Arens dan Lubic (2010: 40) mengatakan bahwa jika auditor tidak dapat mengumpulkan cukup bukti untuk menyimpulkan apakah laporan keuangan yang diaudit jika mereka sesuai dengan prinsip akuntansi yang diterima secara umum, ruang lingkup audit terbatas. Ruang lingkup audit dilakukan karena dua alasan. Pertama, pembatasan yang dihasilkan dari kendala klien. Kedua, hambatan yang muncul dari luar kekuatan auditor atau klien. Contoh pembatasan yang disebabkan oleh pelanggan seperti manajemen enggan mengizinkan auditor untuk mengkonfirmasi hak material.

\section{Gaya kepemimpinan}

Miftah (2007: 49) menemukan bahwa gaya kepemimpinan ialah norma kode etik perilaku yang digunakan oleh seseorang untuk mencoba mempengaruhi perilaku orang lain seperti yang mereka lihat. Menurut Veithzal Rivai (2004: 64), gaya kepemimpinan dapat didefinisikan sebagai perilaku dan strategi sebagai hasil dari serangkaian filosofi, keterampilan, atribut dan situasi yang sering diterapkan oleh seorang pemimpin ketika mencoba mempengaruhi kinerja bawahannya. .

Kepemimpinan dalam pemerintahan menjadi poin kompetitif dalam mencetuskan keputusan atas hal hal yang dirasa penting agar semua hal itu menjadi daya ntung dikemudian hari. Mereka tetap menjadi kesemaptan yang utama memberikan kompresitas untuk menjadi hal yang baik di mata pemerintah. Ketika pemimpinan menjadikan setiap kejadian di masa lalu, memberikan aspek pengaruh dalam kompetensi di mata pegawai. Hal ini menjadikan gaya kepemimpinan menjadi pengaruh aspek penting dalm pemerintahan ataupun OPD.

Dari berbagai gagasan di atas, dapat disimpulkan bahwa gaya kepemimpinan utama mengandung pengertian sebagai manifestasi dari perilaku seorang pemimpin, yang terkait dengan kemampuannya untuk memimpin.

\section{Pengaruh Kualitas Audit terhadap Efektivitas Pengendalian Internal}

Auditor internal ialah karyawan perusahaan dengan tugas utama untuk menentukan apakah kebijakan dan prosedur yang ditetapkan oleh manajemen telah dipenuhi, apakah kekayaan organisasi dilindungi atau tidak, menentukan efektivitas efektivitas prosedur kegiatan organisasi, dan menentukan kualitas informasi yang dihasilkan oleh berbagai bagian organisasi. Penelitian Susiani (2017) menemukan bahwa kualitas audit benar-benar menentukan apakah pengendalian internal efektif atau tidak sehingga tujuan organisasi dalam pengendalian internal dapat tercapai sehingga tingkat efektivitas dan efisiensi operasi lebih baik. Yadnyana (2006) menemukan dalam studinya "Dampak layanan internal Uditor pada efektivitas pengendalian internal di hotel bintang empat dan lima di Bali" bahwa kualitas layanan auditor mempengaruhi tetapi tidak secara signifikan mempengaruhi efektivitas kontrol internal.

H1: Kualitas Audit mempengaruhi Efektivitas Pengendalian Internal 


\section{Pengaruh Lingkup Audit terhadap Efektivitas Pengendalian Internal}

Ruang lingkup audit ialah batas yang diizinkan oleh tim audit untuk dapat menerapkan prosedur inspeksi, apakah ditentukan oleh tujuan (program atau proyek), lokasi (pusat, wilayah, cabang, atau perwakilan), waktu (tahun fiskal, tahun fiskal, semester) atau kuartal). (BPK RI, 2008: 21) Adhitya (2006) mengatakan bahwa faktor-faktor yang membatasi dalam ruang lingkup audit mendorong akuntan publik untuk memberikan pendapat tidak adil lainnya tanpa kecuali. Audit memiliki dampak positif pada pertimbangan memberikan pendapat untuk mencapai tujuan audit. Saat mengumpulkan bukti ini, auditor sering menemukan batasan pada ruang lingkup audit. Dewey Research (2015) memperoleh temuan penelitian bahwa ruang lingkup audit secara parsial memengaruhi efektivitas pengendalian internal. Semakin banyak kegiatan kooperatif, semakin komprehensif dan canggih lingkup pekerjaan penyelia.

H2: Ruang lingkup audit mempengaruhi efektivitas pengendalian internal.

\section{Pengaruh Gaya Kepemimpinan terhadap Efektivitas Pengendalian Internal}

Menurut COSO (2004) lingkungan etis institusi mencakup aspek metode manajemen puncak dalam mencapai tujuan organisasi, nilai-nilai manajemen dan kepemimpinan. Sudarta (2017) menemukan bahwa gaya kepemimpinan memiliki dampak positif pada efektivitas sistem kontrol internal. Hubungan antara Gaya Kepemimpinan Ketua LPD dengan Efektivitas, di mana LPD ialah tingkat gaya kepemimpinan seseorang. Ketika Ketua LPD memengaruhi atau mengarahkan bawahannya dan memiliki kemampuan khusus di bidang yang dipimpin, semakin efektif kontrol internal LPD. Wijaya (2016) menemukan bahwa Gaya Kepemimpinan memiliki efek positif terhadap efektivitas penerapan sistem kontrol internal. Budiarsana (2017) menunjukkan bahwa hasil penelitian gaya kepemimpinan badan pengawas berpengaruh positif dan signifikan terhadap efektivitas sistem pengendalian internal Lembaga Kredit Desa (LPD) di Kabupaten Buleleng.

H3: Gaya kepemimpinan mempengaruhi efektivitas pengendalian internal.

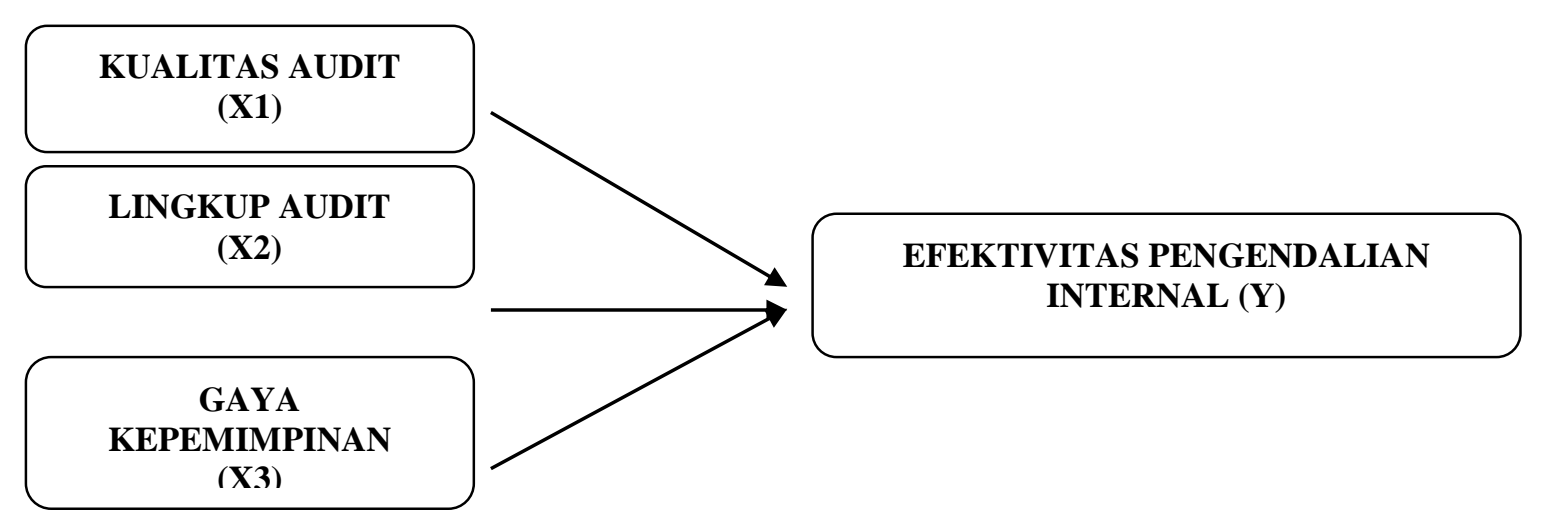

Gambar 1. Kerangka Konseptual

\section{METODE PENELITIAN}

\section{Populasi dan Sampel}

Populasi dalam penelitian ini ialah karyawan tetap (PNS) yang bekerja di OPD di Kota Padang, berjumlah 22 OPD. Dari 22 OPD yang ada, peneliti mengambil 5 sampel untuk setiap 
OPD, termasuk: kepala departemen, sekretaris, bendahara, dan 2 kepala seksi. Sehingga jumlahnya ialah 110 sampel. Teknik pengambilan sampel yang digunakan ialah quota sampling.

\section{DEFINISI OPERASIONAL DAN PENGUKURAN VARIABEL Variabel tak bebas}

Variabel dependen atau terikat dalam penelitian ini ialah efektivitas pengendalian internal. Pengukuran variabel ini menggunakan 5 item pertanyaan yang dikembangkan oleh (COSO, 2004) dengan skala Likert 1 hingga sangat tidak setuju dan 5 sangat setuju.

\section{Variabel bebas}

\section{Kualitas audit}

Kualitas audit diukur dengan menggunakan beberapa pernyataan dewan pelaporan keuangan (2006: 16) yang diukur menggunakan skala Likert 1-5, di mana 1 sangat tidak setuju dan 5 sangat tidak setuju.

\section{Lingkup audit}

Ruang lingkup audit tersirat oleh dua batasan, yaitu: ruang lingkup audit yang luas dan batasan yang disebabkan oleh keadaan di luar klien. Alat ukur yang digunakan ialah menggunakan kuesioner yang dikembangkan dari penelitian oleh Adhitya (2006). Penelitian tentang variabel ruang lingkup audit menggunakan skala Likert 1-5, (1) sangat tidak setuju sampai (5) sangat setuju.

\section{Gaya kepemimpinan}

Gaya kepemimpinan ialah persepsi karyawan tentang seorang pemimpin dalam proses mempengaruhi orang atau bawahan sehingga mereka akan berusaha, mau dan antusias dalam mencapai tujuan kelompok. Variabel gaya kepemimpinan ini diukur oleh indikator yang dikembangkan oleh Fiedler dalam Wicaksono (2013) sebagai berikut (a) Hubungan antara Pemimpin dan bawahan, (b) Struktur tugas, (c) Posisi kekuatan. Pengukuran menggunakan teori Fiedler dalam Wicaksono (2013) dengan item pernyataan dengan skala likert 1-5 yaitu (1) sangat tidak setuju sampai (5) sangat setuju.

Uji asumsi klasik dalam penelitian ini ialah uji heteroskedastisitas, uji multikolinieritas, dan analisis regresi berganda dengan model berikut.

Dimana:

$$
\mathrm{Y}=\alpha+\beta 1 \mathrm{X} 1+\beta 2 \mathrm{X} 2+\beta 3 \mathrm{X} 3+\beta 4 \mathrm{X} 4+\mathrm{e}
$$

$\mathrm{Y}=$ efektivitas pengendalian internal

$\alpha=$ konstan.

$\beta 1 . . \beta 3=$ koefisien regresi dari setiap variabel independen.

$\mathrm{X} 1=$ kualitas audit

$\mathrm{X} 2$ = ruang lingkup audit

$\mathrm{X} 3$ = gaya kepemimpinan

$\mathrm{e}=$ kesalahan 


\section{HASIL DAN PEMBAHASAN Statistik Deskriptif}

Tabel 1

\begin{tabular}{cccccc}
\hline \multicolumn{6}{c}{ Descriptive Statistics } \\
\hline Variabel & N & Terbawah & Maximum & Mean & Std. Deviation \\
\hline X1 & 96 & 24 & 30 & 26.75 & 1.465 \\
\hline X2 & 96 & 6 & 12 & 9.64 & 1.171 \\
\hline X3 & 96 & 12 & 30 & 24.02 & 2.862 \\
\hline Y & 96 & 15 & 25 & 19.55 & 2.224 \\
\hline
\end{tabular}

Sumber : Data primer yang diolah, 2020

Tabel 1 di atas diketahui hasil statistik deskriptif untuk variabel yang diuji dalam penelitian ini meliputi nilai terbawah, nilai teratas, rata-rata dan standar deviasi. Hasil penelitian untuk statistik deskriptif dikenal untuk variabel dependen (efektivitas kontrol internal) bahwa nilai ratarata untuk vsriabel ialah 19,55 dengan standar deviasi 2,224. Nilai teratas untuk variabel efektivitas kontrol internal teratas ialah 25, sedangkan nilai terendah untuk vsriabel ini ialah 15.

Variabel independen pertama dalam penelitian ini ialah kualitas audit memiliki nilai ratarata 26,75 dengan standar deviasi 1,465. Sementara itu, nilai teratas untuk variabel kualitas audit ialah 30, maka jumlah terbawah untuk variabel kualitas audit ialah 24 . Variabel independen kedua dalam penelitian ini ialah bahwa ruang lingkup audit memiliki nilai rata-rata 9,649 lebih lanjut dengan standar deviasi 1,171. Nilai teratas untuk variabel cakupan audit ialah 12, sedangkan nilai terbawah untuk variabel cakupan audit ini ialah 6. Variabel gaya kepemimpinan ialah variabel independen ketiga dalam penelitian ini dengan nilai rata-rata 24,02. Hasil dari tabel menunjukkan untuk kategori standar deviasi 2,862. Variabel gaya kepemimpinan memiliki nilai teratas 30 dan jumlah terbawah untuk variabel ini ialah 12.

Dari penjelasan di atas, ia memberikan informasi bahwa data dalam penelitian ini beragam dan mengandung variasi, diketahui bahwa standar deviasi menunjukkan bahwa semua variabel memiliki nilai lebih besar dari 0 .

\section{Uji Normalitas}

Tabel 2

Hasil Uji Normalitas

\begin{tabular}{llr}
\hline \multicolumn{2}{l}{ One-Sample Kolmogorov-Smirnov Test } & \\
\hline & & Unstandardized Residual \\
\hline $\mathbf{N}$ & & 96 \\
\hline Normal Parameters ${ }^{\text {a,b }}$ & Mean & .0000000 \\
\cline { 2 - 3 } & Std. Deviation & 2.09030577 \\
\hline Most Extreme Differences & Absolute & .112 \\
\cline { 2 - 3 } & Positive & .062 \\
\cline { 2 - 3 } & Negative & -.112 \\
\hline Kolmogorov-Smirnov Z & & 1.094 \\
\hline Asymp. Sig. (2-tailed) & & .183 \\
\hline
\end{tabular}

Sumber: Data primer yang diolah, 2020

Dari hasil Tabel 2 di atas, ini memberikan informasi bahwa nilai Asymp.Sig (2-tailed) ialah 0,183, di mana angka ini lebih besar dari 0,05. Maka disimpulkan data dalam penelitian ini berdistribusi normal. 


\section{Uji Heterokedastisitas}

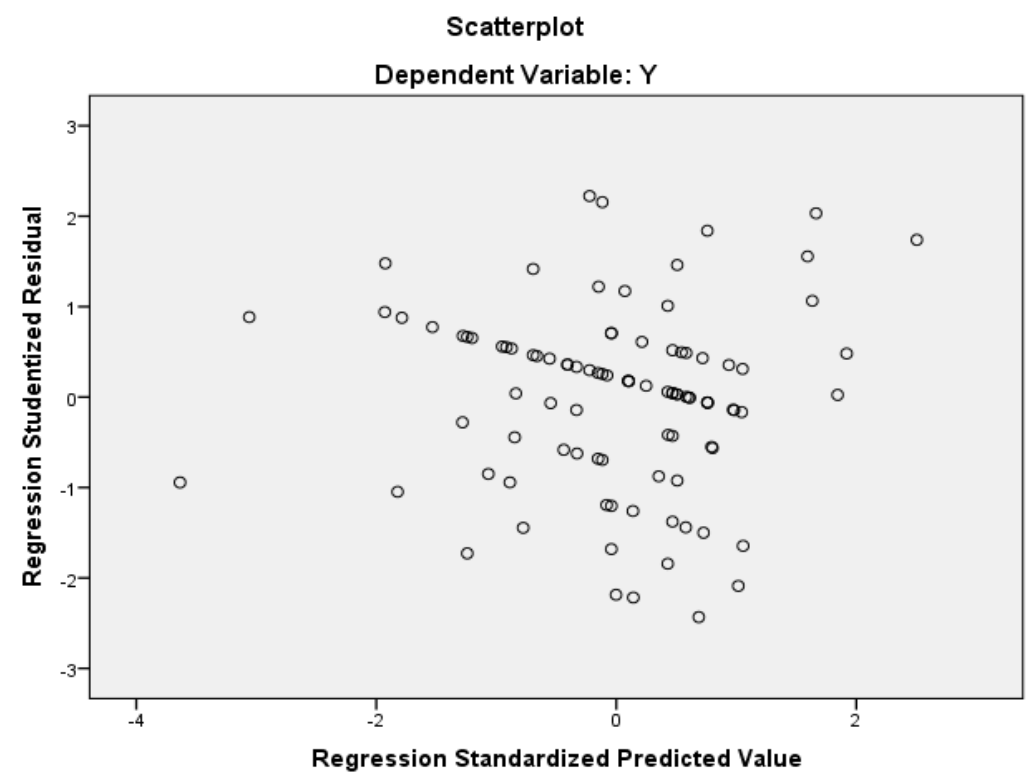

Gambar 2 Hasil Scatterplot Uji Heterokedastisitas

Sumber: Data primer yang diolah, 2020

Hasil uji heterokedastisitas di atas menunjukkan tidak ada heteroskedastisitas atau varians yang sama di antara pengamatan lainnya. Ini dapat dilihat dari Gambar 2, di mana scatterplot menunjukkan titik-titik penyebaran naik dan turun atau terbentuk secara tidak teratur dan membentuk pola pada angka 0 dan sumbu $\mathrm{Y}$ dan nilai signifikansi variabel independen lebih dari 0,05 .

\section{Uji Multikolinearitas}

\section{Tabel 3}

Hasil Uji Multikolinearitas

\begin{tabular}{|c|c|c|}
\hline \multicolumn{3}{|c|}{ Coefficients $^{\mathrm{a}}$} \\
\hline \multirow[b]{2}{*}{ Model } & \multicolumn{2}{|c|}{ Collinearity Statistics } \\
\hline & Tolerance & VIF \\
\hline \multicolumn{3}{|c|}{1 (Constant) } \\
\hline $\mathrm{X} 1$ & 1.000 & 1.000 \\
\hline $\mathbf{X} 2$ & .999 & 1.001 \\
\hline $\mathbf{X 3}$ & .999 & 1.001 \\
\hline
\end{tabular}

Berdasarkan Tabel 3 dapat dilihat dari tidak ada variabel independen yang memiliki nilai Toleransi kurang dari 0,10 nilai Variance Inflation Factor (VIF) dari tiga variabel tidak lebih dari 10. Variabel kualitas audit 1.000, ruang lingkup audit variabel 1,001, variabel gaya kepemimpinan 1,001. Hasil ini menunjukkan bahwa model regresi ini tidak terjadi multikolinieritas. 


\section{Analisi Regresi Berganda}

Tabel 4

Hasil Regresi Berganda

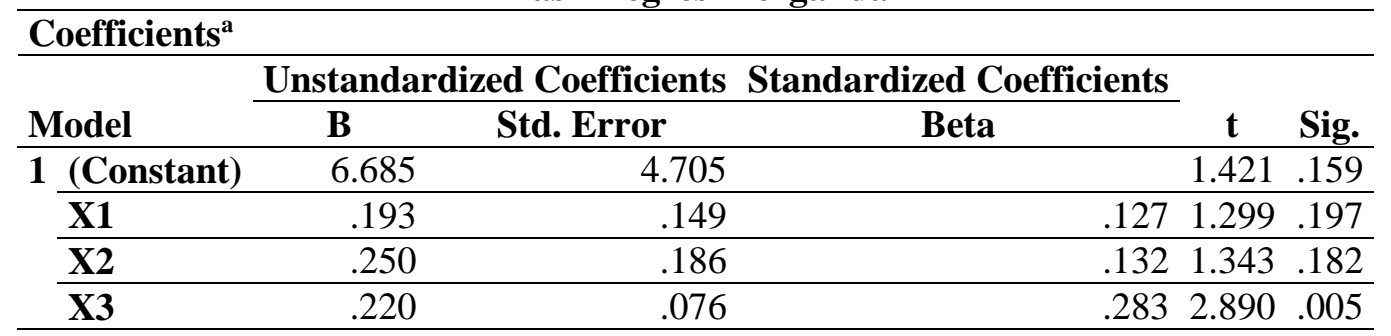

Sumber: Data primer yang diolah, 2020

Hasil dari tabel 4 maka dapat ditulis dari persamaan regresi sebegai berikut :

$$
\mathrm{Y}=6,685+0,193+0,250+0,220+\mathrm{e}
$$

Dapat dilihat dari tabel 4 di atas dapat dilihat bahwa nilai a $=6.685$, artinya jika Kualitas Audit (X1), Lingkup Audit (X2), Gaya Kepemimpinan (X3) ialah 0, efektivitas pengendalian internal ialah $=6.685$. Nilai koefisien untuk X1 sebesar 0,193 bernilai positif, jika jika Kualitas Audit meningkat sebesar $1 \%$ maka akan diikuti oleh peningkatan efektivitas pengendalian internal sebesar 6,685. Ini juga berlaku ketika X2 telah meningkat sebesar 1\%, diikuti oleh peningkatan efektivitas pengendalian internal sebesar 0,250. Nilai koefisien untuk Gaya Kepemimpinan X3 0,220 ialah positif, jika Gaya Kepemimpinan meningkat sebesar 1\% akan diikuti oleh peningkatan Efektivitas Pengendalian Internal sebesar 0,220.

\section{Uji Hipotesis}

\section{Uji F}

Uji simultan (Uji F) digunakan untuk mengetahui sejauh mana variabel- variabel independen secara bersama-sama berpengaruh terhadap variabel dependen. Hasil uji statistik F dapat dilihat dalam Tabel 5 berikut:

Tabel 5

Hasil Uji F

\begin{tabular}{|c|c|c|c|c|}
\hline \multicolumn{5}{|l|}{ ANOVA $^{\mathrm{a}}$} \\
\hline Model & Sum of Squares df & Mean Square & $\mathbf{F}$ & Sig. \\
\hline 1 Regression & $54.649 \quad 3$ & 18.216 & 4.037 & $.010^{\mathrm{b}}$ \\
\hline Residual & 415.09192 & 4.512 & & \\
\hline Total & $469.740 \quad 95$ & & & \\
\hline
\end{tabular}

Sumber: Data primer yang diolah, 2020

Hasil Uji-F pada Tabel 5 untuk menguji pengaruh kualitas audit, lingkup audit, dan gaya pemerintahan F-hitung sebesar 4,037. Tingkat signifikansi pada tabel 5 kurang dari 0,05 dan Fhitung sebesar 4,037 > F-Tabel sebesar 2,70 sehingga dapat disimpulkan bahwa kualitas audit, lingkup audit, dan gaya kepemimpinan berpengaruh terhadap efektivitas pengendalian internal.

\section{Uji t}

Hasil uji T dapat dilihat pada tabel 4, di mana hasil uji-T untuk Hipotesis 1 diperoleh dengan nilai sig. sebesar 0,197> dari 0,05. Ini berarti bahwa Hipotesis 1 dalam penelitian ini ditolak, sehingga disimpulkan bahwa tidak ada pengaruh kualitas audit terhadap efektivitas 
pengendalian internal, dan besarnya efek parsial ialah 0,193 positif. Ini memberikan penjelasan bahwa jika variabel independensi meningkat sebesar 1 skor, efektivitas kontrol akan meningkat sebesar 0,193 dengan asumsi variabel lain dianggap konstan.

Hasil uji-t untuk Hipotesis 2 diperoleh dengan nilai sig. sebesar 0,182. Nilai signifikan dari variabel lingkup audit menunjukkan nilai di atas tingkat 0,05 yang berarti hipotesis ditolak atau tidak ada pengaruh ruang lingkup audit terhadap efektivitas pengendalian internal. Besarnya dampak ruang lingkup audit ialah bagian dari .250. Ini berarti bahwa jika variabel lingkup audit meningkat sebesar 1 derajat, efektivitas pengendalian internal akan meningkat sebesar $=0,250$, dengan asumsi bahwa variabel lain dianggap konstan.

Hasil uji-t untuk Hipotesis 3 diperoleh nilai sig. sama dengan 0,005> 0,05 yang berarti bahwa Hipotesis 3 dapat diterima atau gaya kepemimpinan mempengaruhi efektivitas pengendalian internal. Pengaruh gaya kepemimpinan ialah 0,220 (positif). Ini berarti bahwa jika variabel gaya kepemimpinan meningkat satu persen, efektivitas pengendalian internal akan meningkat sebesar 0,220, dengan asumsi bahwa variabel lain konstan.

\section{Uji Koefisien Determinasi}

\section{Tabel 6}

Hasil Uji Koefisien

\begin{tabular}{lrrrr}
\hline \multicolumn{4}{l}{ Model Summary } \\
\hline Model & R & R Square & Adjusted R Square & Std. Error of the Estimate \\
\hline $\mathbf{1}$ & $.341^{\mathrm{a}}$ & .116 & .088 & 2.124 \\
\hline
\end{tabular}

Sumber: Data primer yang diolah, 2020

Hasil analisis regresi berganda diperoleh koefisien korelasi berganda Adjusted R Square (Adj R2) sebesar 0,088 atau 8,8\%. Jadi disimpulkan bahwa 8,8\% dari variabel efektivitas pengendalian internal dijelaskan oleh empat variabel independen yaitu kualitas audit, ruang lingkup audit, gaya kepemimpinan. Sedangkan sisanya $(100 \%-8,8 \%=91,2 \%)$ disebabkan oleh variabel lain di luar model.

\section{Pembahasan \\ Kualitas Audit Terhadap Efektivitas Pengendalian Internal.}

Kualitas audit dalam penelitian ini juga diukur berdasarkan persepsi karyawan yang bekerja di OPD di Padang. Pada tabel 4 dapat dilihat bahwa hasil signifikan 0,197. Nilai signifikansi untuk variabel kualitas audit menunjukkan nilai di atas tingkat signifikansi 0,05 yang berarti bahwa hipotesis 1 ditolak atau tidak ada pengaruh kualitas audit terhadap efektivitas pengendalian internal, sehingga hipotesis untuk yang pertama pada penelitian ini ditolak.

Hasil penelitian ini tidak sejalan dengan penelitian Susiani (2017) yang menemukan bahwa kualitas audit benar - benar menentukan apakah pengendalian internal efektif atau tidak sehingga tujuan orgsanisasi dapat dicapai dalam pengendalian internal untuk mencapai tingkat efektivits dan efiaiensi yang lebih baik. operasi. Studi ini menemukan bahwa norma-norma pengawasan ialah indikator yang menentukan kualitas layanan auditor internal dalam melaksanakan praktik audit. Jika hal ini terkait dengan pekerjaan auditor internal untuk menilai efektivitas pengendalian internal perusahaan, semakin lengkap indikstor yang dipatuhi oleh auditor internal, semakin efektif pengendalian internal lembaga tersebut.

Hasil ini sesuai dengan fenomena yang terjadi di Kota Padang, Provinsi Sumatera Barat, bahwa hasil BPK RI dalam laporan keuangan provinsi Sumatera Barat mendapat opini WTP, artinya auditor sangat berkualifikasi, tetapi BPK pusat memiliki Republik Indonesia meragukan 
hal ini krena kecurangan masih terjadi di beberapa OPD di Kota Padang. Dapat disimpulkan bahws kualitas audit tidak mempengaruhi efektivitas pengendalian internal dalam OPD di Padang.

\section{Lingkup Audit Terhadap Efektivitas Pengendalian Internal.}

Hipotesis kedua dalam penelitian ini ialah ruang lingkup audit. Ruang lingkup audit tidak terbukti berpengaruh pada efektivitas pengendalian internal. Hasil uji T untuk ruang lingkup audit diperoleh nilai signifikansi 0,182. Nilai signifikan untuk variabel lingkup audit ialah 0,05, yang berarti nilai signifikansinya ialah 0,182. 0,05 yang berarti tidak ada pengaruh ruang lingkup audit terhadap efektivitas pengendslian internal dalam OPD di seluruh Kota Padang.

Berbeda dengan Putra (2017) yang menystakan ruang lingkup pekerjaan memiliki dampak positif dan signifikan terhadap efektivitas sistem pengendalian internal. Hubungan antara ruang lingkup pekerjaan pengendalian internal BUMD dan efektivitas pengendalian internal ialah bahwa semskin tinggi ruang lingkup audit akan meningkatkan efektivitas pengendalian internal. Berbeda dengan penelitian Putra dan Dewi, hasil penelitian ini membuktikan bahwa ruang lingkup audit tidak mempengaruhi efektivitas pengendalian internal. Hasil penelitian ini didukung oleh fenomena yang terjadi yaitu temuan-temuan pendapat Badan Pemeriksa Keuangan Indonesia dalam laporan keuangan WTP Provinsi Sumatera Barat, artinya ruang lingkup audit atau batas audit tidak terbatas. Namun, Badan Pemeriksa Keuangan Indonesia pusat meragukan msalah ini karena kecurangan masih terjadi. Jadi dapat disimpulkan bahwa ruang lingkup audit tidak mempebgaruhi efektivitas pengendslian internal OPD Kota Padang.

\section{Gaya kepemimpinan Terhadap Efektivitas Pengendalian Internal}

Hipotesis ketiga dalam penelitian ini terbukti mempengaruhi efektivitas pengendalian internal. Hasil ini dapat dilihat dari tabel 4 di mana nilai signifikansi untuk variabel gsya kepemimpinan ialah 0,005, yang berarti di bawah nilai signifikan untuk variabel gaya kepemimpinan ialah 0,05, yang berarti bahwa hipotesis ketiga diterima atau pengaruh gaya kepemimpinan terhadap efektivitas pengendalian internal.

Mirip dengan pnelitian yang dilakukan oleh Rae dan Subramanian (2008) yang menemukan bhwa ada pengaruh antara lingkungan etis dan prosedur pengendalian internal yang memoderasi pengaruh keadilan organisasi terhadap kecurangan karyawan, sementara COSO (2004) juga menemukan dalam lingkungan etiis dari suatu Organisasii mencakup apek gaya manajemen puncak dalam mencapai tujuan organiisasi, nilai-nilai dan gaya manajemenn atau kepemimpinan mereka, sehingga dapat dikatakan bahwa dalam lingkungan etis yang dibentuk oleh gaya kepemimpinan dapat mengarah pada pelaporan dan kinerja karyawan yang lebih efektif.

Sejalan dengan penelitian oleh Rae, COSO, dan Sudarta (2008) hasil penelitian ini membuktikan bahwa gaya kepemimpinan mempengaruhi efektivitas pengendalian internal OPD di Kota Padang. Itu karena para pemimpin agen di kota Padang memiliki hubungan yang baik dengan bawahan mereka, pebagian struktur yang baik dan pembagian tugas dari masing-masing karyawan agen yang baik telah menyebabkan kontrol internal yang efektif dalam OPD di seluruh Kota Padang. Dapat disimpulkan bahwa gaya kepemimpinan mempengaruhi efektivitas pngendalian internal di OPD Kota Padang, karena semakin baik hubungan antara pemimpin dan bawahannya, semakin baik kontrol internal. 


\section{KESIMPULAN, KETERBATASAN, DAN SARAN \\ Kesimpulan}

Berdasarkan hasil penelitian yang dilakukan pada pengaruh kualitas audit, ruang lingkup audit, dan gaya kepemimpinan terhadap efektivitas pengendalian internal di sektor pemerintahan, dapat disimpulkan sebagai berikut: a) Kualitas audit tidak mempengaruhi efektivitas pengendalian internal. , b) Ruang lingkup audit tidak mempengaruhi efektivitas pengendalian internal, dan c) Gaya kepemimpinan mempengaruhi efektivitas pengendalian internal.Saran

\section{Keterbatasan}

Penelitian ini memiliki beberapa keterbatasan diantanya, peneliti hanya meneliti pada pemerintah Kota Padang, hasil yang berbeda akan didapatkan pada objek yang lebih luas dan salah satu variabel penelitian ini yaitu Lingkup Audit masih terbatas.

\section{Saran}

Penulis memberikan masukan untuk peneliti selanjutnya agar menggukan responden yang berbeda atau diluar pegawai Dinas se-Kota Padang sehingga dapat diketahui seberapa besar persepsi pengaruh variabel kualitas audit terhadap efektivitas pengendalian internal. Penelitian selanjutnya dapat memperluas objek penelitian yaitu pemerintah Kabupaten/Kota seluruh Indonesia, serta menambah variabel yang dapat mempengaruhi contohnya: tata kelola pemerintahan dan independensi.

\section{DAFTAR PUSTAKA}

Adhitya, Chandra. (2006). "Faktor-Faktor Yang Mendorong Akuntan Publik Memberikan Pendapat Selain Wajar Tanpa Pengecualian”. Skripsi. Fakultas Ekonomi Universitas Widyatama. Surabaya

Badan Pemeriksaan Keuangan. (2010). Opini Laporan Keuangan Pemerintah Daerah Di Indonesia 2006-2010. www.bpk.co.id. (25 November 2011)

COSO. 2004. Enterprise risk management - integrated framework. Committee of Sponsoring Organizations.

Dewi, N. Budhi Cyntia. (2015). Pengaruh Independensi, Pengalaman Kerja, Keahlian Profesional, Motivasi, Dan Ruang Lingkup Pekerjaan Audit Pengawas Pada Efektivitas Pengendalian Intern Koperasi. Jurnal Akuntansi Program S1. 3(1)

Ghozali, Imam. (2011). Aplikasi Analisis Multivariate dengan Program SPSS. Semarang: Badan Penerbit Universitas Diponegoro

Guy, Dan M, Wayne Alderman dan Alan J Winters. (2001). Auditing. Edisi Kelima, Jakarta : Erlangga

Miftah Toha. (2007). Kepemimpinan Dalam Manajemen. Jakarta: PT. Raja Grafindo Persada.

Nurvitria Mei Wulandari. (2010). "Pengaruh Kompetensi dan Profesionalisme Auditor Internal terhadap Kualitas Audit (Studi Kasus pada Inspektorat Kabupaten Magelang dan Inspektorat Kabupaten Sleman)". Skripsi. FISE.UNY

Putra, I Putu Agus Kirana. Nyoman Trisna Herawati dan I Gusti Ayu Purnamawati. 2017. "Pengaruh Independensi, Kompetensi, Dan Ruang Lingkup Pekerjaan Pengawas Internal Terhadap Efektivitas Sistem Pengendalian Intern Bum Desa Se-Kecamatan Kubutambahan Kabupaten Buleleng”. Jurusan Akuntansi Program S1, 8(1). 
Rae and Subramaniam.2008. "Quality Of Internal Control Procedures Antecedents And Moderating Effect On Organisational Justice And Employee Fraud”. Managerial Auditing Journal, 23(2), 104-124.

Ravianto, J. (2014). Produktivitas dan Pengukuran. Jakarta: Lembaga Sarana Informasi

Rivai, Veitzhal. 2004. Manajemen Sumber Daya Manusia untuk Perusahaan Cetakan Pertama. Jakarta: PT. Raja Grafindo Persada.

Susiani, Rini. Edison, Acep. 2017. "Pengaruh Kualitas Audit terhadap Efektivitas Pengendalian Internal". Widyatama Repository

Spence, Michael. 1973. “Job Market Signaling”. The Quarterly Journal of Economics, Vol. 87(3), 355-374

Undang - undang Nomor 23 Tahun 2014 tentang Pemerintah Daerah.

Wicaksono, Widi Cahyo. 2013. "Faktor-Faktor Yang Mempengaruhi Efektivitas Pengendalian Intern di Sektor Pemerintahan (Persepsi Pegawai Pada Dinas-Dinas Kota Semarang)”. Fakultas Ekonomi. Universitas Negeri Semarang. Semarang.

Wijaya, Widi Angga. Rina Arifati dan Agus Suprojanto. 2016. "Analisis Pengaruh Independensi, Motivasi, Pengalaman Kerja, Profesionalisme, Dan Gaya Kepemimpinan Terhadap Efektivitas Penerapan Sistem Pengendalian Intern”. Journal Of Accounting, 2(2).

Wilopo. 2006. "Analisis Faktor-Faktor Yang Mempengaruhi Kecenderungan Kecurangan Akuntansi”. Simposium Nasional Akuntansi IX.

Wilopo. 2008. "Pengaruh Pengendalian Internal Birokrasi Pemerintah dan Pelaku Tidak Etis Birokrasi terhadap Kecurangan Akuntansi Di Pemerintah Persepsi Auditor Badan Pemeriksa Keuangan”. Jurnal Ventura, 11(1).

Yadyana, I Ketut. 2006. "Pengaruh Kualitas Jasa Auditor Terhadap Efektivitas Pengendalian Intern Pada Hotel Berbintang Empat dan Lima Di Bali”. Fakultas Ekonomi Universitas Udayana. Bali. 